\title{
Prevalence and factors associated with minor psychiatric disorders in hospital housekeeping workers*
}

\author{
Prevalência e fatores associados aos distúrbios psíquicos menores \\ em trabalhadores do serviço hospitalar de limpeza \\ Prevalencia y factores asociados con los disturbios psíquicos menores \\ en trabajadores del servicio hospitalario de limpieza
}

Cintia da Silva Marconato ${ }^{1}$, Ana Carolina de Souza Magnago², Tânia Solange Bosi de Souza Magnago², Graziele de Lima Dalmolin², Rafaela Andolhe ${ }^{2}$, Juliana Petri Tavares ${ }^{3}$

How to cite this article:

Marconato CS, Magnago ACS, Magnago TSBS, Dalmolin GL, Andolhe R, Tavares JP. Prevalence and factors associated with minor psychiatric disorders in hospital housekeeping workers. Rev Esc Enferm USP. 2017;51:e03239. DOI: http://dx.doi.org/10.1590/S1980-220X2016026303239

* Extracted from the dissertation "Distúrbios psíquicos menores em trabalhadores do Serviço Hospitalar de Limpeza”, Universidade Federal de Santa Maria, 2015.

${ }^{1}$ Universidade Federal de Santa Maria, Hospital Universitário, Santa Maria, RS, Brazil.

${ }^{2}$ Universidade Federal de Santa Maria, Santa Maria, RS, Brazil.

${ }^{3}$ Centro Universitário Metodista, Porto Alegre, RS, Brazil.

\begin{abstract}
Objective: Investigating the prevalence and factors associated with minor psychiatric disorders (MPDs) in Hospital housekeeping workers. Method: A cross-sectional study carried out in 2013 with workers from the cleaning service of a public university hospital in Rio Grande do Sul, Brazil. Data were collected through a form containing sociodemographic, occupational, habits and health variables. The Self-Reporting Questionnaire-20 was used in order to evaluate MPDs. Results: The study population consisted of 161 workers. The overall prevalence of suspected MPD was 29.3\%. The chances of suspected MPDs were higher in workers with Effort-Reward Imbalance, those who did not have time or who occasionally had time for leisure activities, and those taking medications. Conclusion: The prevalence of MPDs was similar to that found in the literature for health workers. Therefore, we consider it important to include these workers in institutional programs for continuing health education.
\end{abstract}

\section{DESCRIPTORS}

Housekeeping, Hospital; Workers; Stress, Psychological; Occupational Health; Occupational Risks. 


\section{INTRODUCTION}

Hospital Housekeeping $(\mathrm{HH})$ workers carry out their activities with the purpose of guaranteeing a clean and pleasant environment to users and health workers with lower risks of contamination ${ }^{(1)}$. They are a part of the organization chart of the institutions as support service workers who can develop their work activities in several scenarios: hospitals, clinics, basic units, and offices, among others ${ }^{(2)}$.

In this study, the hospital environment is highlighted as a place of work for $\mathrm{HH}$ workers, who, although not directly performing activities with the patients, are exposed to the implications that this conviviality can bring to their health. No technical training is required when hiring these professionals. They receive training on the activities they will perform and are presented with the rules and routines of the institution ${ }^{(1)}$. After this training they are inserted into the work routine where they begin to experience the peculiar subjectivity of the hospital environment, from which we can highlight living with the pain, suffering and death of some patients. This is a very different reality for health workers who have an academic background and have specific disciplines to help them understand and cope with such situations.

In addition, the hospital environment is a place that exposes workers to various risks of illness (physical, biological and mental, for example) and other aggravating factors such as the lack of physical, material and human resources, which can have repercussions on physical and mental illness ${ }^{(3-4)}$. Among the mental risks, we emphasize minor psychiatric disorders (MPDs), which is the focus of this study, and which can lead to insomnia, fatigue, irritability, forgetfulness, difficulty in concentrating and somatic complaints such as headaches, stomach pain and lack of appetite ${ }^{(5)}$. They are considered mild psychiatric disorders, and are not part of the International Classification of Diseases - ICD10 ${ }^{(6)}$. In order to measure them, the World Health Organization (WHO) requested a group of researchers to develop a questionnaire, called the Self-Reporting Questionnaire-20 (SRQ 20), which is characterized as being a screening instrument that is easy to apply and can be used for studies with the most varied populations ${ }^{(6)}$.

Scientific evidence points to high prevalence of MPDs (20.6\% to $51.1 \%)$ among workers working in the hospital environment, such as in nursing workers and in professional medicine, nursing, nutrition and public health residents ${ }^{(7-8)}$. Few studies have been published regarding investigations with $\mathrm{HH}$ workers mainly referring to this issue. Four studies were found by a search carried out in June 2015 in the databases of Latin American and Caribbean Literature in Health Sciences (LILACS), Medical Publications (PubMed), the Theses and Dissertations Bank of the Brazilian Nursing Association (Associação Brasileira de Enfermagem - ABEn) and of the Coordination Portal for the Improvement of Higher Education Personnel (Coordenação de Aperfeiçoamento de Pessoal de Nivel Superior - CAPES). Of these, only one contemplated the theme of mental disorders, although it did not refer to MPDs.

In this context, we question the prevalence and factors associated with MPDs in Hospital Housekeeping workers.
Thus, this study aims to investigate the prevalence and factors associated with MPDs in Hospital Housekeeping workers from a public university hospital in Rio Grande do Sul state, Brazil, in order to address this issue.

\section{METHOD}

This is a cross-sectional study carried out with $\mathrm{HH}$ workers in a medium-sized public university hospital in the countryside of the Rio Grande do Sul state, Brazil. HH workers are divided into cleaning crew teams and auxiliary materials cleaning teams. They are part of an outsourced service within the referred institution, and are covered by a service contract based on the workers law consolidation (Consolidação das Leis Trabalbistas - CLT).

The study population consisted of $161 \mathrm{HH}$ workers. Of these, two (1.2\%) were excluded for being on health leave. From the eligible population $(\mathrm{N}=159), 157$ answered the questionnaire (98.7\%). Losses (1.3\%) were the result of refusals.

Inclusion criteria adopted were: being an outsourced professional who has been working in $\mathrm{HH}$ for a period of 30 days or more prior to data collection, and meeting the SRQ-20 requirement. Workers who were on leave or away for any reason during the collection period were excluded.

The data collection instrument was composed of questions regarding independent variables: sociodemographic variables (gender, age, schooling, marital status, number of children and income); occupational variables (occupation, work shift, has worked in another sector, works overtime, the number of people on the work shift, has received training and has another job), health variables (smoking, alcohol consumption - $\mathrm{CAGE}^{(9)}$, musculoskeletal pain - $\mathrm{MEP}^{(10)}$, medical care in the last year, use of medication, psychological monitoring in the last year, number of diseases with medical diagnosis, work leave/time away from work, Work Ability Index - WAI ${ }^{(11)}$, occupational stress [Effort-Reward Imbalance - ERI $]^{(12)}$ and time for leisure activities).

WAI is a search form designed in Finland by a group of researchers to assess the employee's ability to carry out their work activities. It was translated, validated and adapted to Brazilian Portuguese in $1997^{(11)}$. It is a self-administered tool composed of 10 items grouped into seven dimensions, and its score varies from seven (worst index) to 49 points (best index) $)^{(11)}$.

In order to assess the presence of perceived musculoskeletal pain in the previous week ${ }^{(10)}$, workers with MPDs were defined as those who initially answered affirmatively to the question 'In the last seven days, have you felt pain or discomfort in any of these regions: neck, shoulders, upper limbs, back, hip, and lower limbs?'The pain rating scale has a score ranging from zero to 10 , where zero represents a total absence of pain, and 10 the most intense pain ever perceived by the individual ${ }^{(10)}$. This variable was evaluated dichotomously (present/absent).

The CAGE questionnaire assesses alcohol abuse or dependence. It was validated in Brazil in $1983^{(9)}$. It consists of four questions relating to the anagram cut-down, annoyed, guilty and eye-opener. The questions have dichotomous answers (Yes/No), and the cut-off point is two affirmative 
answers, suggesting positive screening for alcohol abuse or dependence ${ }^{(9)}$.

The self-applied ERI scale translated and validated in Brazil $^{(12)}$ is composed of 23 questions. Six evaluate effort, 11 reward, and six excessive commitment. Questions regarding effort present dichotomous responses (agree or disagree). There are four Likert scale response options for the participants who indicated "I agree" in items 1 to 6 and 10 to 13, ranging from "not at all stressed" to "very stressed"

The same options are present for "disagree" in questions 7-9 and 14-17. Responses to the six items of "extrinsic effort" and to the eleven "reward" items are scored on a five-point scale, ranging from 1 (not stressful) to 5 (very stressful). The score of each dimension is initially calculated to analyze the relationship between effort and reward. The effort dimension ranges from 6 to 30 (six questions with scores between 1 and 5) and the reward dimension varies from 11 to 55 (11 questions with scores between 1 and 5) $)^{(12)}$.

For each participant, a ratio was constructed using the formula: $\mathrm{e} /\left(\mathrm{r}^{*} \mathrm{c}\right)$, where " $\mathrm{e}$ " is the score regarding the effort questions, " $r$ " is the score obtained by the sum of the reward questions, and " $c$ " is a correction factor $(0.545454)$, considering the number of items in the numerator compared to the denominator (6/11). Values close to zero indicate favorable conditions (referring to low effort and high reward), and values higher than 1 indicate greater effort made and lower received reward ${ }^{(12)}$.

Workers who presented scores above the value corresponding to the third tertile of the distribution were classified as "exposed" to the effort-reward imbalance (high ERI), while the others (first and second tertiles) were included in the "unexposed" group (low ERI). High ERI corresponds to the high-risk group for occupational stress (a situation of high effort and low reward).

The dependent variable MPD was collected through the Self-Report Questionnaire (SRQ-20), a self-administered instrument indicated by the WHO to evaluate suspicion of MPDs, and validated for Portuguese ${ }^{(13)}$. This form contains 20 questions with dichotomous answers (Yes/No), in which a score of 1 indicates that the symptoms were present in the last month, and zero which means they were absent. The cutoff point used to define suspected MPDs was six or more positive responses for men and eight or more for women, according to the instrument's user manual ${ }^{(13)}$.

Data were collected in 2013 by interviewers previously trained by the researcher. The collection team included undergraduate Nursing students, Masters students in the Graduate Nursing Program and nurses from the referred Hospital. The researchers involved in the project were committed to data privacy and confidentiality.

Participants who agreed to participate in the research signed the Free and Informed Consent Term two ways, with one being in the participant's possession and the other in the researchers' possession. The research instrument was completed during the interviewees' work shift (morning, afternoon, evening and night) in a private location.

Data were entered in the Epi-info ${ }^{\circledR}$ program, version 6.4, with double independent typing. After checking for errors and inconsistencies in typing, data analysis was performed in the PASW Statistics ${ }^{\circledR}$ program (Predictive Analytics Software, SPSS Inc., Chicago, USA) version 18.0 for Windows. Descriptive and inferential statistics were used. Absolute $(\mathrm{N})$ and relative (\%) frequencies were calculated for the categorical variables, while mean, standard deviation, median, minimum and maximum were calculated for quantitative variables. The Kolmogorov-Smirnov test was performed to verify the distribution of data normality. Finally, Fisher's Chi-Square or Exact test at a significance level of 5\% were adopted for verifying associations between MPDs (dependent variable) and other variables.

Multivariate analysis adjusted for confounding factors (variables associated with the outcome with $\mathrm{p}<0.15$ ) was performed through Poisson Regression. Prevalence ratios (PRs) of their respective confidence intervals $(95 \% \mathrm{CI})$ were used to estimate associations. Variables where $\mathrm{p}<0.05$ were significantly associated with the outcome.

This study complies with Resolution 466 of December 12, 2012, and the project was approved by the Research Ethics Committee of the institution, under Opinion Number 205.862, of February 25, 2013.

\section{RESULTS}

The workers were predominantly females $(n=138$; $87.9 \%$ ) with a mean age of 39.9 years $(\mathrm{SD}=9.78$, minimum of 19 and maximum of 60 years), with complete secondary education $(n=86,54.8 \%)$, married/with partner $(n=101$, $64.3 \%)$, with up to three children $(n=114,72.6 \%)$ and per capita family income lower than one national minimum wage $(n=103 ; 66 \%)$.

Regarding occupational variables, hospital housekeeping service workers predominated $(n=103,65.6 \%)$, who performed their duties during the day $(n=127,81 \%)$, who had already worked in another sector of the institution $(n=99$, $63 \%)$, who did not work overtime ( $n=106,67.5 \%)$, they considered the number of workers on the work shift sufficient $(\mathrm{n}=116,73.9 \%)$, they received in-service training $(\mathrm{n}=113$; $72 \%)$ and did not have another job ( $n=139,88.5 \%)$.

Regarding the health variable, non-smokers $(n=79$, $50.3 \%)$ and those who did not consume alcohol $(n=140$, $89.1 \%$ ) prevailed. Of those who consumed alcoholic beverages, $35.3 \%(n=6)$ had a suspicion for alcohol abuse or dependence (CAGE Test). Also, workers who reported the presence of musculoskeletal pain $(n=110,70.1 \%)$ prevailed, who needed medical care in the last year $(n=92,58.6 \%)$, who were taking medication $(n=80,51 \%)$, and who needed psychological counseling $(n=10,6.3 \%)$. We also observed a predominance of workers who reported having no disease with a medical diagnosis $(n=47,29.9 \%)$, who did not need to go on a leave in the last year $(n=89,56.7 \%)$ and had good/excellent work ability (WAI) ( $n=125,79.6 \%)$. Regarding exposure to occupational stress (ERI), 33.1\% $(n=52)$ were classified into the exposed group (high ERI), and in terms of leisure time, workers who had time $(n=93$, $59.2 \%$ ) prevailed.

Overall prevalence for MPDs among $\mathrm{HH}$ workers was 29.3\%. The mean positive responses evidenced in SRQ-20 
were 4.25 (SD 3.74). Half of the workers had three positive responses (IQ 1-6), a minimum of zero and a maximum of 15 positive responses. The group of symptoms with the highest prevalence was Depressing-anxious mood, ranging from $21 \%(n=33)$ to $55.4 \%(n=87)$. Out of the 20 questions, the ones with the highest prevalence of positive responses were: "Feeling nervous, tense or worried" with $55.4 \%(n=87)$ of the answers, followed by "having frequent headaches" with $40.1 \%$ ( $n=63$ ), "finds it difficult to make decisions" with $29.9 \%(\mathrm{n}=47)$, and "have lost interest in things" with $17.2 \%(\mathrm{n}=27)$.
No statistically significant association between MPDs, socio-demographic variables or occupational variables was found ( $p>0.05)$. Regarding variables related to workers' health, significant statistical associations $(\mathrm{p}<0.05)$ were evidenced with: Use of medication (38.8\%; $n=31$ ); number of diagnosed diseases (15.8\% to 60\%); exposure to occupational stress $(55.8 \% ; n=29)$; presence of musculoskeletal pain (36.4\%; $n=40)$; work leave (39.7\%; $n=27)$; not having time for leisure $(64.7 \%, \mathrm{n}=11)$; and low work ability $(56.3 \%, \mathrm{n}=18)$.

Table 1 shows gross and adjusted associations between MPD and variables with $p$-value $<0.15$.

Table 1 - Distribution of gross and adjusted associations, according to sociodemographic, occupational and health variables - Rio Grande do Sul, Brazil, 2013.

\begin{tabular}{|c|c|c|c|c|c|c|}
\hline Variables & PRg & $95 \% \mathrm{Cl}$ & $\mathbf{p}$ & PRad & $95 \% \mathrm{Cl}$ & $\mathbf{p}$ \\
\hline \multicolumn{7}{|l|}{ Number of children } \\
\hline More than 3 children & 1.05 & $0.85-1.29$ & 0.624 & -- & -- & -- \\
\hline Up to 3 children & 0.90 & $0.76-1.06$ & 0.216 & -- & -- & -- \\
\hline None & 1.00 & -- & -- & -- & -- & -- \\
\hline \multicolumn{7}{|l|}{ Per capita Family Income } \\
\hline$<1$ salary & 1.11 & $0.99-1.24$ & 0.072 & 1.06 & $0.95-1.17$ & 0.277 \\
\hline 1 to 2 salaries & 1.00 & -- & -- & 1.00 & -- & -- \\
\hline \multicolumn{7}{|l|}{ Work shift } \\
\hline Day & 1.13 & $0.99-1.29$ & 0.058 & 0.98 & $0.84-1.09$ & 0.518 \\
\hline Night & 1.00 & -- & -- & 1.00 & -- & -- \\
\hline \multicolumn{7}{|l|}{ Use of medication } \\
\hline Yes & 1.16 & $1.04-1.29$ & 0.006 & 1.11 & $1.02-1.22$ & 0.011 \\
\hline No & 1.00 & -- & -- & 1.00 & -- & -- \\
\hline \multicolumn{7}{|l|}{ Medical care } \\
\hline Yes & 1.08 & $0.97-1.21$ & 0.141 & 1.00 & $0.91-1.10$ & 0.870 \\
\hline No & 1.00 & -- & -- & 1.00 & -- & -- \\
\hline \multicolumn{7}{|l|}{ Psychological follow-up } \\
\hline Yes & 1.173 & $0.94-1.45$ & 0.145 & 1.09 & $0.91-1.30$ & 0.322 \\
\hline No & 1.00 & -- & -- & 1.00 & -- & -- \\
\hline \multicolumn{7}{|c|}{ Diseases with medical diagnosis } \\
\hline 5 or more diseases & 1.27 & $1.09-1.48$ & 0.002 & 1.09 & $0.94-1.27$ & 0.241 \\
\hline 4 diseases & 1.29 & $0.97-1.72$ & 0.075 & 1.24 & $0.90-1.71$ & 0.184 \\
\hline 3 diseases & 1.14 & $0.94-1.38$ & 0.171 & 0.93 & $0.77-1.12$ & 0.472 \\
\hline 2 diseases & 0.92 & $0.78-1.08$ & 0.312 & 0.89 & $0.77-1.02$ & 0.118 \\
\hline 1 disease & 0.93 & $0.81-1.07$ & 0.373 & 0.91 & $0.81-1.03$ & 0.142 \\
\hline No disease & 1.00 & -- & -- & 1.00 & -- & -- \\
\hline \multicolumn{7}{|l|}{ Occupational Stress (ERI) } \\
\hline High & 1.34 & $1.20-1.49$ & $<0.0001$ & 1.22 & $1.08-1.38$ & 0.001 \\
\hline Low & 1.00 & -- & -- & 1.00 & -- & -- \\
\hline \multicolumn{7}{|l|}{ Musculoskeletal pain } \\
\hline Yes & 1.20 & $1.08-1.34$ & 0.001 & 1.03 & $0.92-1.16$ & 0.583 \\
\hline No & 1.00 & -- & -- & 1.00 & -- & -- \\
\hline \multicolumn{7}{|l|}{ Work leave } \\
\hline Yes & 1.15 & $1.03-1.28$ & 0.011 & 0.98 & $0.88-1.09$ & 0.763 \\
\hline No & 1.00 & -- & -- & 1.00 & -- & -- \\
\hline \multicolumn{7}{|l|}{ Time for leisure } \\
\hline No & 1.43 & $1.23-1.66$ & $<0.0001$ & 1.22 & $1.04-1.43$ & 0.012 \\
\hline Occasionally & 1.25 & $1.19-1.41$ & $<0.0001$ & 1.18 & $1.06-1.31$ & 0.002 \\
\hline Yes & 1.00 & -- & -- & 1.00 & -- & -- \\
\hline \multicolumn{7}{|l|}{ Work Ability } \\
\hline Low to Moderate & 1.27 & $1.12-1.44$ & $<0.0001$ & 1.02 & $0.89-1.18$ & 0.712 \\
\hline Good to Excellent & 1.00 & -- & -- & 1.00 & -- & -- \\
\hline
\end{tabular}

* PRg: Gross Prevalence Ratio. PRad: Adjusted Prevalence Ratio. 95\% CI: Confidence Interval. p: p-value. 
After adjusting for confounding factors (variables associated with the outcome with $\mathrm{p}<0.15$ ), those that remained associated with MPDs were: taking medication ( $\mathrm{PRad}=1.11$, 95\% CI=1.02-1.22), high occupational stress ( $\mathrm{PRad}=1.22$, 95\% CI=1.08-1.38), not having time for leisure ( $\mathrm{PRad}=1.22$, 95\% CI=1.04-1.43) and only occasionally having time for leisure $(\mathrm{PRad}=1.18,95 \% \mathrm{CI}=1.06-1.31)$.

\section{DISCUSSION}

In Brazil, a systematic review study revealed high prevalence rates of mental disorders in the adult population, mainly affecting women and workers $(20 \% \text { to } 56 \%)^{(14)}$. The prevalence of MPDs among $\mathrm{HH}$ workers in this study is included in this variation.

A study carried out in four government hospitals in the city of Zagazig (Egypt) in comparing the SRQ-20 responses of cleaning workers with temporary and permanent work ties found a significantly higher proportion of common mental disorders in temporary workers (59.1\%) compared to permanent workers (29.7\%) (OR: 3.4, 95\% CI: 2.27-5.17). In Egypt, the overall prevalence of mental disorders in the adult population is $16.9 \%{ }^{(15)}$.

In this study, the prevalence of MPDs in HH workers compared to workers in the hospital environment was higher than that verified in a study carried out with a multiprofessional health team (physicians, psychologists, speech therapists, social workers, occupational therapists, physiotherapists and a nursing team) of the Hospital de Clinicas da Universidade Federal do Triângulo Mineiro $(27.9 \%)^{(16)}$. This result indicates that $\mathrm{HH}$ professionals are exposed to the risks of mental suffering, with indications that there may be a higher prevalence of illness than in health workers working in the hospital environment.

In view of this, it is necessary to consider a lack of academic preparation of $\mathrm{HH}$ professionals regarding the confrontation of mental demands. Health workers have specific disciplines during their training period to better deal with situations of pain and suffering in the hospital environment. Such evidence points to the need for $\mathrm{HH}$ workers to also be a part of programs to prevent psychological suffering from work.

In the analysis of the groups of symptoms proposed by the SRQ-20, the results evidenced here corroborate those of other studies carried out with health workers of the Municipality of João Pessoa, Paraíba state ${ }^{(17)}$, and with professors of undergraduate nursing courses at the seven federal universities of Rio Grande do Sul state ${ }^{(18)}$. In these studies, the depressinganxious mood symptom group also prevailed, with a higher percentage of affirmative answers to the question "feeling nervous, tense or worried", being $81 \%$ and $49.2 \%$, respectively.

This fact may reflect a moment of change in the labor market and the current crisis in the financial system, in which a worker may be flooded with anguish and uncertainty. Thus, these feelings can directly affect the health of workers, generating wear and mental suffering, and the suffering in the case of workers in the hospital environment can be aggravated by being around humans in some of the most difficult moments of their lives; moments of illness and finality.
Another result evidenced in this study that deserves to be highlighted is the group of symptoms related to depressing thoughts, which presented sensitive issues despite not having such high prevalence; issues in this group are related to the inability of having a meaningful role in life, lack of interest in things, having thoughts of taking their own life and feeling useless. These questions may indicate the existence of intense psychological suffering in some workers and even the risk of suicide.

Other studies ${ }^{(19-20)}$ have also demonstrated the result evidenced here, indicating that suicide of workers may be related to mental suffering resulting from the work itself. Countries such as France and Japan have data on workrelated suicide, which is attributed to an intensification of work and overwork, to the lack of solidarity between the work team and psychological and moral harassment.

Regarding the analysis adjusted for confounding factors, we found that suspicion of MPDs was associated with taking medication, high stress at work, not having time or only occasionally having time for leisure (Table 1). Taking medication had an $11 \%$ higher prevalence for presenting MPDs than those who did not use drugs. We consider that, depending on how the difficulties and demands imposed by occupational activities are faced, they can trigger a process of physical and mental illness in workers. In more severe cases, it is necessary to use some type of medication to help them overcome or face difficulties. Also, it is necessary to emphasize that MPDs provoke physical and psychological symptoms in workers such as insomnia, headache, fatigue, irritability and gastralgia ${ }^{(5)}$, which often lead to taking medication to alleviate them.

In this regard, it should be considered that the occupational process of $\mathrm{HH}$ workers requires great physical effort when performing activities such as sweeping, scrubbing and sanitizing. These actions are repeated countless times during the same work shift. In this way, they can also favor the occurrence of musculoskeletal pain, which leads to taking medication. In a screening test (urine) for multiple substances, an Egyptian study evidenced a greater proportion of tramadol use (39.7\% versus $20.6 \%$ ) in cleaning workers with temporary contracts compared to those with a permanent work tie (OR: 2.5, 95\% CI: 1.63-3.96) $)^{(15)}$.

Pain can cause mental effects in individuals such as irritability, insomnia and even social isolation due to one's own pain and/or misunderstanding by colleagues or bosses. However, the relationship between pain and suspicion of MPDs should be better explored in future studies, since the association between these variables in this study was not significant in the adjusted analysis.

High occupational stress (high ERI) was another factor associated with suspected MPDs. For workers who had a high imbalance between undertaken effort and received reward, suspected MPDs were 22\% higher than those at low imbalance. Work stress was also evidenced in Egypt among temporary cleaners compared to those with permanent bonds (OR: 2.2; 95\% CI: 1.36-3.54). According to the authors, this result can be attributed to the poor quality of informal work and low remuneration ${ }^{(15)}$. 
In analyzing studies with health workers ${ }^{(21-22)}$, occupational stress among $\mathrm{HH}$ professionals is similar to the result of a study on the psychosocial stress of nurses working in oncology, in which one of the variables that showed a significant association with high ERI was the variable of feeling sad/depressed ${ }^{(21)}$.

Likewise, a positive association between high ERI, a state of depression and anxiety was identified in a study with Japanese nurses ${ }^{(22)}$. Based on these results we can infer that there must be a balance between the demands made to workers and the rewards given to them, otherwise the worker will incur in mental suffering. However the reward can not only be financial; recognition of the work done, attitudes and commitment to the community, both by teammates and other colleagues and management also constitute a form of reward.

Furthermore, although the activities carried out by $\mathrm{HH}$ workers are fundamental not only for safer health care of the workers but also for workers' health, they may suffer from the invisibility commonly faced on a day to day basis, as their work is seen as supportive, meaning that they are only remembered when their work is not adequately performed; and this "invisibility" can be a triggering factor of work stress and mental suffering.

Also, not having time or only occasionally having time for leisure presented $22 \%$ and $18 \%$ higher prevalence of suspected MPDs. In agreement with this, a study carried out with workers from the urban area of Feira de Santana/Bahia state and with socio-educative agents from Rio Grande do Sul state also showed a higher prevalence of MPDs in the group of individuals with no leisure time ${ }^{(23-24)}$.

Females are pointed out as a factor that can interfere in the lack of time for leisure ${ }^{(25)}$. As seen in this study, $\mathrm{HH}$ is predominantly performed by women, married/with partner, with up to three children and a per capita household income less than one minimum wage. It is assumed these women likely have a double duty, because when they have a day off, they often end up performing tasks very similar to those they do at their work. Thus, there seems to be no time left for leisure and recreation, which is an important strategy for preventing work-related mental disorders such as MPDs.
Encouraging workers to dedicate part of their time off work for performing activities that provide them pleasure and satisfaction is also an employers and managers' responsibility, since the prevention of MPDs is the most appropriate strategy for maintaining workers' mental health.

\section{CONCLUSION}

The prevalence of MPDs in $\mathrm{HH}$ workers was high, demonstrating that these workers are exposed to similar risks as health workers. Regarding the associated factors (taking medication, being exposed to high stress at work, and not having time or only occasionally having time for leisure), these may be related to the occupational process of $\mathrm{HH}$ workers, as they perform repetitive activities with high physical and mental strain.

Thus, we found that housekeeping hospital workers, who are essential for patient and workers' safety, should be the focus of a larger number of studies addressing different themes. This will enable an elaboration for diagnosing the work situations experienced by them, as well as for their health conditions and the specific risks to which they are exposed.

We also suggest that $\mathrm{HH}$ workers are included in multiprofessional groups for the collective discussion of mental suffering experienced in the work environment, assuming that collective and multiprofessional discussions are a protective factor for workers' mental health. The meetings should be included in the work shift, and be coordinated by formally trained professionals.

The results identified in this study also point out the need for nurses, as researchers and members of Occupational Health and Safety services, to broaden their horizons by proposing studies with professionals other than those in the health area, as they can suggest changes in routines and processes based on scientific evidence, thus contributing to the prevention of physical and mental occupational illnesses.

We can consider the cross-sectional design as a limitation of this study, since there is reverse causality bias. We suggest further studies comparing the prevalence of MPDs and associated factors among $\mathrm{HH}$ and health workers.

\section{RESUMO}

Objetivo: Investigar a prevalência e os fatores associados aos Distúrbios Psíquicos Menores (DPMs) em trabalhadores do Serviço Hospitalar de Limpeza. Método: Estudo transversal, realizado em 2013, com trabalhadores do serviço de limpeza de um hospital universitário público do Rio Grande do Sul, Brasil. Os dados foram coletados por meio de um formulário contendo variáveis sociodemográficas, laborais, hábitos e saúde. Para avaliação dos DPMs utilizou-se do Self-Reporting Questionnaire-20. Resultados: A população do estudo foi composta pelos 161 trabalhadores. A prevalência global para suspeição de DPM foi de 29,3\%. As chances de suspeição de DPMs foram maiores nos trabalhadores em Desequilíbrio Esforço-Recompensa, nos que não tinham ou às vezes tinham tempo para o lazer e naqueles que faziam uso de medicação. Conclusão: A prevalência de DPMs assemelhou-se à encontrada na literatura em trabalhadores da área saúde. Portanto, considera-se importante a inclusão desses trabalhadores em programas institucionais de educação permanente em saúde.

DESCRITORES

Serviço Hospitalar de Limpeza; Trabalhadores; Estresse Psicológico; Saúde do Trabalhador; Riscos Ocupacionais.

\section{RESUMEN}

Objetivo: Investigar la prevalencia y los factores asociados con los Disturbios Psíquicos Menores (DPMs) en trabajadores del Servicio Hospitalario de Limpieza. Método: Estudio transversal, realizado en 2013 con trabajadores del servicio de limpieza de un hospital universitario público de Río Grande do Sul, Brasil. Los datos fueron recogidos mediante un formulario conteniendo 
variables sociodemográficas, laborales, hábitos y sanidad. Para la evaluación de los DPMs se utilizó el Self-Reporting Questionnaire-20.

Resultados: La población del estudio estuvo compuesta de los 161 trabajadores. La prevalencia global para sospecha de DPM fue del 29,3\%. La probabilidad de sospecha de DPMs fue mayor en los trabajadores en Desequilibrio Esfuerzo-Recompensa, en los que no tenían o solo a veces tenían tiempo para el ocio y en los que utilizaban medicación. Conclusión: La prevalencia de DPMs se asemejó a la encontrada en la literatura en trabajadores del área de la salud. Por lo tanto, se considera importante la inclusión de dichos trabajadores en programas institucionales de educación sanitaria permanente.

\section{DESCRIPTORES}

Servicio de Limpieza en Hospital; Trabajadores; Estrés Psicológico; Salud Laboral; Riesgos Laborales.

\section{REFERENCES}

1. Brasil. Ministério da Saúde; Agência Nacional de Vigilância Sanitária. Segurança do paciente em serviços de saúde: limpeza e desinfecção de superfícies [Internet]. Brasília; 2012 [citado 2015 out. 23]. Disponível em: http://www20.anvisa.gov.br/segurancadopaciente/index. php/publicacoes/item/seguranca-do-paciente-em-servicos-de-saude-limpeza-e-desinfeccao-de-superficies

2. Petean E, Costa ALRC, Ribeiro RLR. Repercussões da ambiência hospitalar na perspectiva dos trabalhadores de limpeza. Trab Educ Saúde [Internet]. 2014 [citado 2015 out. 23];12(3):615-35. Disponível em: http://www.scielo.br/scielo.php?script=sci_arttext\&pid $=$ S1981-77462014000300615

3. Martins JT, Ribeiro RP, Bobroff MCC, Marziale MHP, Robazzi MLCC, Mendes AC. Meaning of workload on the view of cleaning professionals. Acta Paul Enferm. 2013; 26(1):63-70.

4. Silva RM, Zeitoune RCG, Beck CLC, Martino MMF, Prestes FC. The effects of work on the health of nurses who work in clinical surgery departments at university hospitals. Rev Latino Am Enfermagem. 2016;24:e2743.

5. Goldberg D, Huxley P. Common mental disorders: a bio-social model. London: Tavistock; 1992.

6. Santos KOB, Araújo TM, Pinho OS, Silva ACC. Avaliação de um instrumento de mensuração de morbidade psíquica: estudo de validação do Self-Reporting Questionnaire (SRQ-20). Rev Baiana Saúde Pública. 2010;34(3):544-60.

7. Urbanetto JS, Magalhães MCC, Maciel VO, Sant'Anna VM, Gustavo AS, Figueiredo CEP, et al. Work-related stress according to the demandcontrol model and minor psychic disorders in nursing workers. Rev Esc Enferm USP [Internet]. 2013 [cited 2015 Oct 23];47(3):1186-93. Available from: http://www.scielo.br/pdf/reeusp/v47n5/0080-6234-reeusp-47-05-1180.pdf. DOI: 10.1590/S0080-623420130000500024

8. Carvalho CN, Filho DAM, Carvalho JAG, Amorim ACG. Prevalência e fatores associados aos transtornos mentais comuns em residentes médicos e da área multiprofissional. J Bras Psiquiatr. 2013;62(1):38-45.

9. Masur J, Monteiro M. Validation of the CAGE alcoholism screening test in Brazilian Psychiatry inpatient hospital setting. J Biol Res. 1983;16(1):215-8.

10. Jensen MP, Karoly P, Braver S. The measurement of clinical pain intensity: a comparison of six methods. Pain. 1986;27(1):117-26.

11. Tuomi K, Ilmarinen J, Jahkola A, Katajarinne L, Tulkki A. Índice de capacidade para o trabalho.São Carlos: Ed. UFSCar; 2005.

12. Chor D, Werneck GL, Faerstein E, Alves MGM, Rotenberg L. The Brazilian version of the effort-reward imbalance questionnaire to assess job stress. Cad Saúde Pública. 2008;24(1):219-24.

13. Mari JJ, Willians P. A validity study of a Psychiatric Screening Questionnaire (SRQ-20) in Primary care in the city of São Paulo. Br J Psychiatry. 1981;148:23-6.

14. Santos EG, Siqueira MM. Prevalence of mental disorders in the Brazilian adult population: a systematic review from 1997 to 2009 . J Bras Psiquiatr. 2010;59(3):238-46.

15. Abbas RA, Hammam RA, El-Gohary SS, Sabik LM, Hunter MS. Screening for common mental disorders and substance abuse among temporary hired cleaners in Egyptian Governmental Hospitals, Zagazig City, Sharqia Governorate. Int J Occup Environ Med. 2013;4(1):1326.

16. Alves AP, Pedrosa LAK, Coimbra MAR, Miranzi MAS, Hass VJ. Prevalência de transtornos mentais comuns entre profissionais de saúde. Rev Enferm UERJ. 2015; 23(1):64-9.

17. Katsurayama M, Parente RCP, Moraes RD, Moretti-Pires RO. Trabalho e sofrimento psíquico na estratégia saúde da família: uma perspectiva Dejouriana. Cad Saúde Coletiva. 2013;21(4):414-9.

18. Tavares JP, Magnago TSBS, Beck CLC, Silva RM, Prestes FC, Lautert L. Prevalence of minor psychiatric disorders in nursing professors. Esc Anna Nery. 2014;18(3): 407-14.

19. Hirata H. Tendências recentes da precarização social e do trabalho: Brasil, França, Japão. Cad CRH. 2011;24(n.esp.):15-22.

20. Ceccon RF, Meneghel SN, Tavares JP, Lautert L. Suicídio e trabalho em metrópoles brasileiras: um estudo ecológico. Ciênc Saúde Colet. $2014 ; 19(7): 2225-3$

21. Rantanen J, Feldt T, Hyvönen K, Kinnunen U, Mäkikangas A. Factorial validity of the effort-reward imbalance scale: evidence from multisample and three-wave follow-up studies. Int Arch Occup Environ Health. 2013;86(6):645-56.

22. Kikuchi Y, Nakaya M, Ikeda M, Narita K, Takeda M, Nishi M. Effort-reward imbalance and depressive state in nurses. Occup Med (Lond). 2010;60(3):231-3.

23. Farias MD, Araújo TM. Transtornos mentais comuns entre trabalhadores de zona urbana de Feira de Santana-BA. Rev Bras Saúde Ocup. $2011 ; 36(123): 25-39$ 
24. Greco PBT, Magnago TSBS, Urbanetto JS, Luz EMF, Prochnow A. Prevalência de distúrbios psíquicos menores em agentes socioeducadores do Rio Grande do Sul. Rev Bras Enferm. 2015;68(1):93-101.

25. Pinho OS, Araúj o TM. Association between housework overload and common mental disorders in women. Rev Bras Epidemiol. 2012;15(3):560-72.

Financial support:

Conselho Nacional de Desenvolvimento Científico e Tecnológico - CNPQ. Process number 481096/2013-2. Universidade Federal de Santa Maria, for support and the PROBIC/FAPERGS/UFSM Scientific Initiation Grant. 